\title{
CREDIT RISKS MITIGATION AND BANKING COLLATERAL VALUATION IN UKRAINE
}

\section{КРЕДИТНІ РИЗИКИ ТА БАНКІВСЬКА ОЦІНКА ЗАСТАВНОГО МАЙНА В УКРАЇНI}

\section{КРЕДИТНЫЕ РИСКИ И БАНКОВСКАЯ ОЦЕНКА ЗАЛОГОВОГО ИМУЩЕСТВА В УКРАИНЕ}

\author{
Yakubovsky V.V.
}

Doctor of technical sciences, professor of the international business department of the Institute of International Relations of Taras Shevchenko National University of Kyiv. E-mail: vyakubovsky@ukr.net

\section{Якубовський В. В.}

Доктор технічних наук, професор кафедри міжнародного бізнесу Інституту міжнародних відносин Київського національного університету ім. Тараса Шевченка.E-mail: vyakubovsky@ukr.net

\section{Якубовский В.В.}

Доктор технических наук, профессор кафедры международного бизнеса Института международных отношений Киевского национального университета им. Тараса Шевченко. e-mail: vyakubovsky@ukr.net

Abstracts. Contemporary international requirements and mechanisms which are oriented to credit risks abatement and assurance of financial sector functioning are reviewed with particulars of their implementation in national banking sector.

As is demonstrated general reasons for the new generation of regulatory measures of crisis resilience in financial sector are grown up from the last global economy crisis which demonstrated vulnerability of the main credit institutions and their failure to absorb considerable financial market fluctuations.

To improve financial systems stability is the main goal of measures and instruments proposed by the international Basel Committee on Banking Supervision as well as Directives and Regulations of the European Union, which should be implemented at the national level.

One of the underlining aspect in this new international regulatory documents is recognition of the assets valuation key role in the whole methodology of risks mitigation. Main approaches to consider time effect on assets valuation results are analyzed in this context.

Based on these last international regulatory documents in this direction special Resolution No. 351of the National Bank of Ukraine has been issued for banks credit risks assessment. Much less attention in this Resolution is given to assets valuation which is linked to some extent with outdated national valuation standards. This situation requires active measures to be provided for updating basic national documents in this area as is underlined.

Key words: credit risks, credit institutions, banking collateral, assets valuation, risks mitigation, international regulations, valuation approaches, time effect, valuation methodology.

Анотація. Розглянуті сучасні міжнародні регуляторні документи, які визначають вимоги до зменшення кредитних ризиків та забезпечення стійкого функиіонування банківського сектору в контексті їх застосування у вітчизняній банківській системі.

Продемонстровано, що головна причина появи нового покоління регуляторних документів цฺього напрямку полягає в негативних наслідках останньої глобальної економічной 
кризи, яка висвітлила слабкості діючої фінансової системи в иілому, неспроможність ї̈ ключових іституцій протидіяти негативному впливу ринкових флуктуацій.

Підвищення стійкості функиіонування всієї фінансової системи як раз $і$ стало головною метою прийнятої Міжнародним Базельським Комітетом з Банківського Нагляду низки документів, які є основою відповідних Директив та Регламентів Свропейського Союзу.

Одним з ключових аспектів цих міжнародних документів регуляторного характеру $є$ визнання значного місия в забезпеченні стійкого функціонування банківського сектору вартісної оцінки заставного майна. В цьому відношенні в роботі розглянуті та проаналізовані існуючі підходи до урахування часового фактору при визначенні вартості різних активів.

Спираючись на ичі міжнародно прийняті документи, національний банк України прийняв спеціальну постанову за № 351, яка встановлює детальний порядок визначення рівня кредитного ризику по активним банківським операчіям. В той же час питанням методології вартісної оцінки залогового майна в даному документі приділено недостатньо уваги. Багато в чому ие пов'язано з загальним відставанням національної регуляторної бази вартісної оцінки матеріальних та нематеріальних активів, щзо визначає необхідність подолання иієєї прогалини та актуалізаџії національних стандартів оцінки.

Ключові слова: кредитні ризики, інститути кредитування, кредитне забезпечення, оцінка активів, зниження ризиків, міжнародне регулювання, підходи очінки, методологія оцінки, часовий ефект.

Аннотация. Рассмотрены современные международные регуляторные документы, определяющие требования к снижению кредитных рисков и обеспечению устойчивого функиионирования банковского сектора в контексте их применения в отечественной банковской системе.

Показано, что основная причина появления нового поколения регуляторных документов данного направления вызвана негативными последствиями последнего глобального экономического кризиса, выявивщего слабости действующей финансовой системы в целом, неспособность ее ключевых элементов противодействовать негативному влиянию рыночных флуктуаций.

Повыпение устойчивости функционирования всей финансовой системь как раз и явилось основной целью принятого Международным Базельским Комитетом Банковского Надзора ряда документов, которые стали основой соответствующих Директив $u$ Регламентов.

Одним з ключевых аспектов этих международных документов регуляторного характера является признание существенной роли в обеспечении устойчивого функиионирования банковского сектора стоимостной оценки залогового имущества. В этих рамках рассмотрены различные подходы к учету временного фактора при определении стоимости активов различных видов.

Опираясь на эти международно принятые документы, нащиональный банк Украины принял специальное Постановление № 351, устанавливающее порядок оценки кредитных рисков по активным операциям украинских банков. Значительно меньшего внимание в этом базовом национальном документе уделено вопросам методологии стоимостной оценки залогового имущества. Во многом это связано с общим заметным отставанием национальной нормативной базы стоимостной оценки материальных и нематериальных активов, что определяет необходимость принятия соответствующих мер по устранению все возрастающего пробела и актуализащии нацииональных стандартов оценки.

Ключевые слова: кредитные риски, институты кредитования, кредитное обеспечение, оченка активов, снижение рисков, международное регулирование, подходь оценки, методология оченки, временной фактор. 
Introduction. The general statement that the stable functioning of the banking sector is one of the dominant features of the efficient functioning of the entire economy has been clearly confirmed by the last global economic crisis of 2007-2009. Significant liberalization of mortgage lending of residential real estate, initiated by the White House in the 1970s, including the simplification of procedures and requirements of insurance, securing loans and the valuation of collateral assets, gradually led to a significant increase in the number of unsecured or so called "toxic" loans.

According to the Harvard University Joint Center for Housing Studies, at the beginning of the century their share reached almost $20 \%$ of total mortgage loans. In absolute terms the number of high-risk loans exceeded 13 million with a total value of more than USD 2 trillion [10, p. 43]. It quickly transformed this "bubble" into a large-scale financial crisis that directly engulfed 165 major international and national banking institutions.

As is well known the overall effects of the crisis have been spectacular. The Dow Jones Index has fall down more than a half with unsecured loans loss totaling around USD 2.8 trillion by 2011 in Europe and America only. The most vulnerable to the global crisis with its sharp decline in commodity turnover were countries with export-oriented and transitional economies including Ukraine. By the level of devaluation, which amounted to $42 \%$ in the second half of 2008 , the Ukrainian hryvnia ranked second in the world after the Icelandic krona with industrial production in the country falling over $34 \%$.

A meticulous analysis of the main causes and effects of the crisis, carried out by a specially established reputable National Commissions of the United States and the International Monetary Fund, have revealed the list of the most important ones. Among them [8, 9]:

- systematic disruption of financial regulation and control, which has had a material adverse effect on the stability of the functioning of financial markets;

- significant weaknesses in corporate and credit risk management in many influential financial institutions;

- the combined negative effect of excess borrowing, risky investing and lack of transparency that were inherent for the entire financial system;

- inconsistency and low standards of mortgage lending and mortgage derivatives;

In this respect a reliable valuation of mortgaged property is recognized as being essential for the overall reliability of financial sector.

Given the magnitude of the global financial crisis which reached a global level, and based on its root causes revealed, international and national institutions have developed and implemented a number of regulative solutions to mitigate the adverse negative effects and prevent recurrences of such drastic events in the future.

Based on this, the purpose of the article is to analyze the measures provided by the relevant international and national regulatory documents and the instruments based on them, aimed at reducing credit risks and strengthening as a result the stability of financial systems as a whole, as well as the peculiarities of their implementation at the national Ukrainian level with respect to the collateral valuation.

Recent researches and publications analysis. Based on the mandate received from the G20 Summits of 2008-2012, the International Basel Committee on Banking Supervision has developed and adopted in a post-crisis period a set of documents, commonly known as Basel III in the development of the previous Basel I and Basel II documents.

The Basel III documents provide for a gradual transition to a new level of regulatory requirements for credit institutions. First of all it concerns the requirements for equity and the provision of high quality and liquidity of credit security or collateral [2, 3].

In its latest document, which came out at the end of 2017 and is considered to be a transition from Basel III to Basel IV, the Basel Committee finalized the regulatory changes, limiting to a large extent the permissible risk weighted assets. These restrictions are structured according to the type of credit institution and its rating level.

Fundamental measures proposed by the Basel III documents are oriented to: 
- improve the ability of the banking institutions to absorb stresses;

- increase the level of risk management and corporate governance standards;

- increase transparency and openness of banking activities.

In addition to a significant increase in banking system-wide operational standards, Basel III envisages a gradual transition to a new level of specific requirements for credit institutions. First and foremost, they relate to equity requirements and the provision of high level of credit collateral liquidity.

At its core, the documents of the Basel Committee on Banking Supervision are internationally agreed standards, developed and adopted by consensus with the participation of representatives of the central banks and supervisory authorities of the most economically developed countries in the world.

Therefore, their status is not legally binding, being mainly of advisory type. Hence in this sense, it seems appropriate to investigate the implementation of these main provisions both at international and national levels.

Main results description. The implementation of the Basel III recommendations in the EU countries has been primarily done through the adoption of Directive 2013/36 / EC (CRD) and Regulation 575/2013 / EC (CRR) on the capital requirements of credit institutions [5,6]. These documents are already mandatory for implementation in all EU countries and should be considered as a single package. If Directive 2013/36/EC on capital requirements establishes general provisions on access to capital and a set of preventative management actions that financial institutions should support, then Regulation 575/2013/EC details the requirements themselves in a structured manner.

The main objective of the new package of European regulatory requirements for credit institutions is to establish a uniform, standard-based approach to responsible lending to reduce solvency, liquidity and excessive leverage risks, as well as to increase their resilience in the face of financial crises as a whole. Fully based on fundamental provisions, including main indicators of the Basel III international agreement, these documents set minimum requirements for banking and investment institutions which are involved in credit operations.

Another important European regulatory document oriented at reducing credit risk is Directive 2014/17/EC [7]. This document, commonly known as the Mortgage Lending Directive, aims to provide the borrowers with greater transparency and awareness of lending conditions and to set higher standards for the provision of support services. In particular, the Directive points to the need to use the most reliable and recognized mortgage valuation standards, which include the International Valuation Standards IVS, the European Valuation Standards EVS and the Royal Institute of Chartered Surveyors RICS standards.

These European regulatory documents stipulate that the value of the collateral assets must not be higher of their market value. In order to apply the most prudent approach, the concept of mortgage value is introduced. This concept was first accepted as a valuation basis in the previous Directive 2006/48/EC and afterwards it was transposed into Regulation 575/2013/EC.

In explaining the notion of mortgage value, both International and European Valuation Standards indicate that when used as a valuation base, mortgage value should be considered for a longer term than the market value which should be determined for a fixed point of time (Fig.). It follows that the collateral value of the property, as a rule, cannot exceed its market value and it should exclude the influence of any speculative elements.

In the most concentrated and detailed form, the requirements for assets valuation are set out in a special Regulation of the European Union 2018/345/EC, which was issued in November 2018. This extended document, which is primarily intended to valuate assets in resolution procedures and to regulate credit institutions insolvency, sets out the full scope of requirements for assets valuation methodology.

In particular, in addition to the market value, mortgage value and fair value, the following new basis of value are introduced:

- hold value;

- disposal value; 
- franchise value.

It is emphasized also that, overall, the valuation methodology should be preferably based on income approach through cash flow discounting. In this context it is probably for the first time when possibility of value range determination is indicated in addition to its point value.

To its full extent, the methodological basis of banking valuation of property and liabilities are described today by two European documents:

- Consolidated Document of the Association of Mortgage Banks of Germany HypZert / VDP- "Mortgage Lending Value”[Grimman, 2016: 245 ],

- European Banking Authority Guide - "EBA Handbook on Valuation for the Purpose of Resolution” [11].

These two documents are most detailed and therefore significant in content. As is stated in particular separate attention should be given to the time effect in collateral assets value. The fact is that, as is well known, under the influence of external (economic cycles, inflation, demand, etc.) and internal (wear, aging, damage, etc.) factors, the market value of mortgage property changes over time. This creates significant problems in determining the level of collateral value, since the terms of the loan agreements are often several years, especially when lending is related to real estate.

Being addressed to this issue, the most common today are 3 approaches based on the following concepts:

- Mortgage Lending Value, MLV, most widely used in Germany;

- Investment Value, IV with more global implementation;

- Adjusted Market Value, AVM, mainly used in UK and Spain.

Comparative testing of these three approaches, carried out by the Property Industry Alliance Working Group, has favored the latter, i.e. the AVM approach [12].

In addition to these three, a more structured approach has been proposed recently which is based on the Long-Term Sustainable Value or L-TSV concept. This concept is grounded on an income approach and introduces such new parameters as:

- sustainable cap-rate;

- sustainable rent-rate,

Both these parameters take into account long-term changes in the market value of assets. Accordingly, well known and widely used Williams-Gordon-Shapiro modified formula has a modified form that also takes into account inflation impact and assets physical deterioration:

$V_{0}$ - Long-Term Sustainable Value;

$$
V_{0}=Y_{1} /\left(i_{r f}+i_{r p}(g+\pi)+d\right)
$$

$Y_{1}$ - Net Operating Income for the next Year;

$i_{r f}$ - Risk-free Yield;

$i_{r p}$ - Property Risk Premium;

$g$ - Yearly Income Growth Rate;

$\pi$ - Inflation Rate;

$d$ - Depreciation Rate.

An example of the application of this approach to German residential real estate valuation using historical data for the period 1991-2017 and projected statistical estimates for the near future demonstrated the feasibility of its further wider testing and utilization [Fischer, 2019: 12].

International experience and practical activity in strengthening the financial system has not been overlooked by the domestic banking sector. The basic document of the national level in this respect is, of course, the widely known Resolution of the National Bank of Ukraine No. 351 dated of June 30, 2016 [1].

The main content of this Resolution, including a number of amendments to it, is the provision on determination of the credit risk level on active banking operations. This Resolution describes in details the methods and procedures for determination of this criterion and sets the level of its compliance. 
In general, this Resolution is entirely based on the principles and recommendations of the Basel Committee on Banking Supervision and takes into account requirements of the relevant European Union policy documents in this area.

At the same time, much less attention has been given to the issues of assets valuation trustworthy. The content of the Resolution in this respect is limited to:

- basic principles for accepting assets in loan collateral;

- determination of the asset types to be accepted as a collateral and their liquidity ratios;

- requirements for monitoring the availability and conditions of such collateral;

- general requirements for the valuation bodies.

Methodologically, the content of these domestic regulatory document, with all the editorial changes, is limited to the provision of "the implementation by banks of collateral valuation at a value that does not exceed market (fair) value and ensures its sale to a third-party buyer." It also points to the need to "re-evaluate the value of collateral ... on a regular basis, in particular, real estates, businesses, land and machinery equipment - at least once a year ...".

There is, evidently, a significant gap between existing international practices and the national valuation requirements for property, property rights and obligations, which are described above. In doing so, we should take into account that, in practice, the valuation of mortgaged property is performed with the reference to the market value.

This certainly casts doubt on the validity and reliability of the results obtained in assessing both the quality of banks' assets and their stress testing results, as the market value is usually higher than the mortgage one or similar type of valuation basis which reflect long-term effect. Accordingly, the value of assets, when the market value is used as a basis for valuation, exceeds its level in comparison with the case of the utilization of mortgage or similar value basis. It means that final results of assets value assessment will be shifted to a non-conservative side.

At the same time, the overall sustainability problems of Ukrainian banking sector remain significant. According to the recent data from The World Bank Group, the share of non-performing or "toxic" loans in the banking sector in Ukraine is the highest among the major post-Soviet countries being equal in 2017 to $54.5 \%$ or more than a half of a total loans number [13]. All this also necessitates the continued adoption of sound regulatory measures.

At the same time, it should be emphasized that the problems of a significant lag in the methodology of valuation are of general type. A simple acknowledgment of this is the fact that, as of today, the national valuation standards which were issued initially in 2003 -2006, and still remain unchanged to this day. Even the very concept of mortgage value is not defined in these standards being classified among other types of valuation basis apart of the market value. Coming from this, regulatory measures necessary should cover not only national banking sector but all assets valuation activity in a country.

Concluding remarks. The recent global economic crisis has revealed significant deficiencies in the functioning of the financial system, its low ability to dampen crisis phenomena. Based on the joint decision of G-20 Summits 2008-2012 a number of international regulatory instruments aimed at strengthening the banking sector were introduced. They include first of all documents of the International Basel Committee on Banking Supervision - Basel III and European Union policy documents, which set out new principles and approaches, as well as criteria for ensuring a more stable functioning of banking institutions including their ability to counteract crisis events.

One of the main outcome from this documents is recognition of core importance of collateral assets valuation. At the same time from a methodological point of view it's important to consider time effect on assets valuation results with respect to the loan agreement duration. Different existing approaches to take into account this effect are reviewed which gave a priority to adjusted market value (AMV) and long-term sustainable value (L-TSV) concepts.

Relying on international documents issued, the National Bank of Ukraine in its Resolution No. 351 also presented regulations for assessments of credit risks in financial institutions. At the same time methodological guidance for collateral assets valuation are covered in this Resolution in 
sufficiently. Partly it is caused by outdated general national valuation standards published in 20032006. From this it became evident necessity to provide sufficient measures for filling in enlarging gap in valuation guidance documents at national level.

\section{References}

1. Postanova Pravlinnya Natsionalnogo Banku Ukrainy ot 30 Chervnya 2016 roku No. 351 «Pro Zatvedjennya Polozheniya pro vyznachennya bankamy Ukrainy rozmiru kreditnogo ryzyku za aktyvnymi bankivskimy operatsayamy (in Ukr.). Available at:

https://bank.gov.ua/control/uk/publish/category?cat_id=8804895

2. Basel Committee on Banking Supervision. Basel III: A Global Regulatory Framework for More Resilient Banks and Banking Systems, December 2010. Available at: http://www.bis.org/publ/bcbs189.pdf

3. Basel Committee on Banking Supervision. Basel III: The Liquidity Coverage Ratio and Liquidity Risk Monitoring Tools, January 2013. Available at: http://www.bis.org/publ/bcbs238.htm.

4. Basel Committee on Banking Supervision. Basel III: Finalizing post-crisis reforms, December 2017. Available at: https://www.bis.org/bcbs/publ/d424.pdf

5. Directive 2013/36/EU on Access to the Activity of Credit Institutions and the Prudential Supervision of Credit Institutions and Investments Firms, 26 June 2013. Available at: http://eur-lex.europa.eu/LexUriServ/LexUriServ.do?uri=OJ:L:2013:176:0338:0436:En:PDF

6. Requlation 575/2013/EU on Prudential Requirements for Credit Institutions and Investments Firms, 26 June 2013. Available at: http://eur-lex.europa.eu/legal-content/en/TXT/?uri=celex\%3A32013R0575

7. Directive 2014/17/EU on Credit Agreements for Consumers Relating to Residential Immovable Property. Available at: http://eur-lex.europa.eu/legalcontent/EN/ALL/?uri=celex\%3A32014L0017

8. Final Report of the National Commission on the Causes of the Financial and Economic Crisis in the United States. Available at: https://www.gpo.gov/fdsys/pkg/GPO-FCIC/pdf/GPOFCIC.pdf.

9. World economic outlook : a survey of the International Monetary Fund. - Washington, DC : International Monetary Fund.- 2009, - 251 p.

10. Harvard Report - State of the Nation’ Housing. 2008 Report/JCHS of Harvard University Press, May 2010.- 124 p.

11. Handbook on Valuation for Purposes of Resolution. European Banking Authority, 2019.- 96 p.

12. Long-term Value Methodologies and Real Estate Lending A report by the Long-term Value Working Group of the Property Industry Alliance Debt Group. Available at: https://www.bpf.org.uk/sites/default/files/resources/Long-term-Value-Methodologies-andReal-Estate-Lending.pdf

13. The World Bank data on non-performing loans.- Available at: https://data.worldbank.org/indicator/fb.ast.nper.zs

14. Grimman W. Mortgage Lending Value, 5-th ed. Verband Deutscher Pfandbriefbanken e.V., 2016.- 245 p.

15. Fischer M. The L-TSV network and current developments in Europe on sustainable valuation concepts. IVSC-WAVO Global Valuation Conference, Frankfurt, June 11-12, 2019. 


\section{MICT}

\section{ПОЛІТИЧНІ ПРОБЛЕМИ МІЖНАРОДНИХ ВІДНОСИН}

Doroshko M. S., But S. A.

China-India's conflict of interest in the region of South Asia.

Lisovskiy P., Lisovska Yu.

A new paradigm of human existence as legal identity in the entropy system. 15

\section{Parfinenko A.}

"The Russian world" on the Budva Riviera: tourism and foreign policy process in the

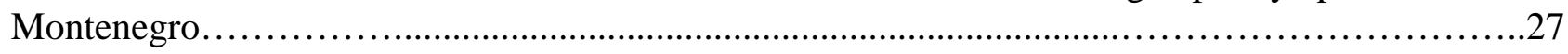

\section{СУЧАСНА СИСТЕМА МІЖНАРОДНОГО ПРАВА}

Medvedieva M.O., Habrelian H. V..

Protection of medical personnel in the context of armed conflict in Ukraine.

Smyrnova K., Sviatun O.

EU-Ukraine association agreement implementation coordination mechanism.... 50

\section{ОСОБЛИВОСТІ РОЗВИТКУ СВІТОВОГО ГОСПОДАРСТВА ТА МЕВ}

\section{Rogach $\mathbf{O}$.}

The political economy of global value chains restructuring.

Yakubovskiy S. O., Rodionova T. O., Tsviakh O. S.

Current state and prospects for the development of the North American free trade area. .74

\section{Reznikova Nataliia V., Rubtsova Maryna Y., Yatsenko Olha M.}

The role of innovation clusters in building up investment and innovation strategies in the crossborder cooperation context

\section{Derkach T.V., Alekseievska H.}

The influence of developed countries central banks' unconventional monetary policy on the economy of Ukraine.

\section{Yakubovsky V.V.}

Credit Risks Mitigation and Banking Collateral Valuation in Ukraine. 109 


\title{
АКТУАЛЬНІ ПРОБЛЕМИ МІЖНАРОДНИХ ВІДНОСИН
}

\author{
Збірник наукових праць
}

\section{ВИПУСК 142}

Заснований в 1996 році.

Засновник : Інститут міжнародних відносин Київського національного університету імені Тараса Шевченка.

Свідоцтво про державну реєстрацію: К1 №292 від 05.11.1998 р.

Перересстрація у 2020 році.

Засновник: Київський національний університет імені Тараса Шевченка.

Свідоцтво про державну ресстрацію: серія КВ №24308-14148ПР від 13.02.2020 р.

Науковий редактор: Дорошко М. С., доктор історичних наук, професор.

Рекомендовано до друку Вченою радою Інституту міжнародних відносин Київського національного університету імені Тараса Шевченка. Протокол № 8 від 3 квітня 2020 року.

Підписано до друку 06.04.2020 року.

Наклад 100 примірників

Інститут міжнародних відносин

Київського національного університету імені Тараса Шевченка

Тел. 044-481-44-68

Сайт: http://apir.iir.edu.ua/index.php/apmv/ 